\title{
Alterações fisiológicas e bioquímicas em sementes de café secas em sílica gel e soluções salinas saturadas
}

\author{
Stefania Vilas Boas Coelho(1), Madeleine Alves de Figueiredo(1), Aline da Consolação Sampaio Clemente(1), \\ Luis Filipe Serafim Coelho(1) e Sttela Dellyzete Veiga Franco da Rosa ${ }^{(2)}$
}

\begin{abstract}
(1)Universidade Federal de Lavras, Departamento de Agricultura, Caixa Postal 3.037, CEP 37200-000 Lavras, MG, Brasil. E-mail: stefaniavbc@gmail.com, madeleine_dede@yahoo.com.br, alineagrolavras@gmail.com, Ifilipesc@gmail.com (2)Embrapa Café, Avenida W3 Norte (Final), Parque Estação Biológica, CEP 70770-901 Brasília, DF, Brasil. E-mail: sttela.rosa@embrapa.br
\end{abstract}

\begin{abstract}
Resumo - O objetivo deste trabalho foi avaliar alterações fisiológicas e bioquímicas em sementes de café submetidas à secagem rápida, em sílica gel, e à secagem lenta, em soluções salinas saturadas. As sementes foram secas até que atingissem os seguintes teores de água: 40,30,20,15, 10 e 5\% (base úmida). Após a secagem, uma parte das sementes foi imediatamente avaliada quanto ao desempenho fisiológico e ao perfil de enzimas do processo oxidativo, e outra parte foi avaliada após armazenagem em condição hermética, em câmara fria e seca, por quatro meses. A velocidade de secagem e o teor final de água tiveram efeito significativo sobre a qualidade fisiológica das sementes. Após a secagem rápida em sílica gel, as sementes toleraram teores finais de água mais baixos. No entanto, após a secagem lenta, as sementes com teores finais de água mais elevados apresentaram maior qualidade. O período de armazenamento não afetou a germinação, mas prejudicou o vigor das sementes. A secagem rápida apresenta maior potencial de dano ao endosperma do que aos embriões. $\mathrm{O}$ perfil enzimático das sementes de café é afetado pelo teor final de água e pela velocidade de secagem.
\end{abstract}

Termos para indexação: Coffea arabica, armazenagem, perfil enzimático, qualidade fisiológica, tolerância à dessecação, velocidade de secagem.

\section{Physiological and biochemical changes in coffee seed dried in silica gel and saturated saline solutions}

\begin{abstract}
The objective of this work was to evaluate the physiological and biochemical changes in coffee seed subjected to rapid drying, in silica gel, or to slow drying in saturated saline solutions. Seeds were dried until they reached the following water contents: 40,30, 20, 15, 10, and 5\% (wet basis). After drying, part of the seeds was immediately evaluated as to their physiological performance and enzymatic profile of the oxidative process, and another part was evaluated after storage, under hermetic conditions, in freeze-drying chamber, for four months. Drying rate and final moisture content had significant effect on seed physiological quality. After rapid drying, in silica gel, seeds tolerated lower final moisture levels. However, after slow drying, seeds with greater water levels showed higher quality. The storage period did not affect germination, but it reduced coffee seed vigor. Rapid drying shows greater damage potential to the endosperm than to the embryos. The enzymatic profile of coffee seed is affected by the final moisture level and the drying rate.
\end{abstract}

Index terms: Coffea arabica, storage, enzymatic profile, physiological quality, desiccation tolerance, drying rate.

\section{Introdução}

As sementes recalcitrantes, diferentemente das ortodoxas, não toleram dessecação nem baixas temperaturas (Roberts, 1973). Sementes de café (Coffea arabica L.) não toleram baixas temperaturas e nem secagem abaixo de $10 \%$ de umidade e são consideradas como de comportamento intermediário (Ellis et al., 1990). Portanto, entre os vários fatores que influenciam a qualidade das sementes de café, o grau de umidade e as condições de secagem e de armazenamento são essenciais, principalmente em razão da sensibilidade dessas sementes à dessecação. Em decorrência de seu comportamento intermediário, as sementes de café têm pouca longevidade, e isso constitui um sério desafio aos produtores de sementes, uma vez que os procedimentos tradicionalmente empregados na secagem e armazenamento podem causar danos irreversíveis à viabilidade delas (Vieira et al., 2007).

A resposta à secagem artificial, em espécies consideradas intermediárias, depende da velocidade 
com que a água é perdida (Caddah et al., 2005; Rosa et al., 2005; Carvalho, 2006; José et al., 2011). Em geral, sementes sensíveis à dessecação podem sobreviver a menores teores de água, se submetidas a uma secagem mais rápida. Neste caso, não há tempo suficiente para que os danos se avolumem durante o processo. No entanto, independentemente da taxa de secagem, há um limite inferior absoluto, abaixo do qual as sementes não sobrevivem (Dussert et al., 2006).

Rosa et al. (2005), ao estudar os efeitos de diferentes taxas de secagem sobre o potencial de armazenamento de sementes de Coffea canephora Pierre, observaram efeitos significativos da velocidade de secagem sobre a qualidade fisiológica e consideraram a velocidade intermediária como a mais adequada a essas sementes. Porém, há evidências de que a secagem rápida pode permitir que se alcancem menores teores de água nas sementes, o que possibilitaria o aumento de longevidade, sem perda da qualidade fisiológica (Berjak, 2006; Dussert et al., 2012). No entanto, os resultados de pesquisa quanto ao melhor método de secagem das sementes de café ainda são inconclusivos. Gentil (2001) verificou que a redução do teor de água de sementes de C. arabica até $10 \%$ e o armazenamento a $10^{\circ} \mathrm{C}$ favorecem a manutenção da qualidade das sementes por até 6 meses. Rosa et al. (2005) concluíram que, independentemente do método de secagem, a umidade a $35 \%$ é prejudicial à qualidade das sementes de café, além de favorecer a incidência de fungos. Silva et al. (2007) relataram que a secagem lenta pode aumentar a tolerância à dessecação de sementes ortodoxas, uma vez que, neste caso, há mais tempo para indução dos mecanismos de proteção à dessecação. Em sementes sensíveis à dessecação, há, também, indicações de que a secagem rápida dificulta a recuperação das sementes, que demoram mais tempo para serem reparadas durante a reidratação (Illing et al., 2005).

A sílica gel é uma alternativa para a secagem rápida de sementes, em bancos de germoplasma. Ela retira a umidade por meio da adsorção física da água, que tem suas moléculas retidas à superfície dos poros do dessecante (José et al., 2009). Normalmente, a sílica gel tem capacidade de adsorção de água de, no máximo, $30 \%$ de seu próprio peso, mas pode ter sua capacidade de adsorção regenerada (José et al., 2011). Para a dessecação de sementes a menores velocidades, o uso de soluções salinas saturadas tem sido utilizado. Segundo Hay et al. (2008), essas soluções mantêm a umidade relativa constante na atmosfera ao seu redor. Assim, quando usadas em recipientes fechados, as soluções salinas saturadas proporcionam uma pressão de vapor constante nos recipientes, a uma determinada temperatura. Portanto, as soluções salinas têm sido largamente utilizadas em pesquisas com a análise da relação entre umidade relativa do ar, temperatura e grau de umidade de equilíbrio das sementes (Bazin et al., 2011; Choudhury et al., 2011).

O objetivo deste trabalho foi avaliar alterações fisiológicas e bioquímicas em sementes de café, submetidas à secagem rápida, em sílica gel, e à secagem lenta, em soluções salinas saturadas.

\section{Material e Métodos}

O trabalho foi realizado no Laboratório Central de Sementes, do Departamento de Agricultura da Universidade Federal de Lavras. Foram utilizadas sementes da safra 2012/2013, da espécie C. arábica 'Catuaí Amarelo IAC 62'. Os frutos foram colhidos na Fazenda Experimental Procafé, em Varginha, à altitude de $980 \mathrm{~m}$, com clima tropical de altitude (Cwb), de acordo com a classificação de Köppen.

Os frutos foram colhidos seletivamente no estádio cereja, nos ramos médios das plantas e nas partes medianas desses ramos. Após a colheita, os frutos foram novamente selecionados, para uniformização do estádio de maturação, e descascados mecanicamente. As sementes foram desmuciladas por fermentação em água, durante 24 horas, e mantidas à sombra, durante a pré-secagem, para a retirada da umidade superficial. Foram utilizadas as sementes retidas na peneira de crivo circular no $20 / 64$, o que corresponde a $8 \mathrm{~mm}$ de diâmetro.

Duas velocidades de secagem foram avaliadas: rápida, em sílica gel; e lenta, com uso de soluções salinas. Em ambos os métodos, as sementes foram secas até que atingissem os seguintes teores de água: 40, 30, $20,15,10,5 \%$ de base úmida (BU). As sementes foram colocadas em camada única sobre telas, no interior de caixas de acrílico do tipo gerbox, lacradas com papel filme para evitar trocas com o ambiente externo.

Para a secagem rápida, a sílica gel ativada foi depositada abaixo das telas, de maneira a evitar o contato com as sementes. A sílica gel perde a capacidade de secagem no decorrer do processo, em razão da adsorção de água das sementes. Assim, ela 
era trocada antes da mudança da coloração que indica alteração em seu conteúdo de umidade.

Para a secagem lenta, foram utilizadas soluções salinas, compostas por três diferentes sais, já que cada composto de sal proporciona uma determinada umidade relativa de equilíbrio em recipiente fechado. Para garantir a secagem das sementes até os teores de água de interesse, por meio do equilíbrio higroscópico entre sementes e atmosfera do recipiente, as soluções salinas foram preparadas pela dissolução em água dos cloretos de sódio, lítio ou magnésio. Para a secagem até $40 \%$ de umidade, utilizou-se o cloreto de lítio ( $\mathrm{LiCl})$, em solução diluída a 5\%; para a umidade de $30 \%$, utilizou-se o cloreto de sódio $(\mathrm{NaCl})$; e para as umidades de $20,15,10$ e 5\%, utilizou-se o cloreto de magnésio hexa-hidratado $\left(\mathrm{MgCl}_{2} \cdot 6 \mathrm{H}_{2} \mathrm{O}\right)$, em solução salina saturada. As concentrações utilizadas dos sais e os valores de umidade relativa de equilíbrio, proporcionadas pela presença das soluções salinas saturadas em recipiente fechado estão sumarizadas na Tabela 1.

A perda de água foi monitorada por pesagens contínuas, em balança de precisão de $0,001 \mathrm{~g}$, até que as sementes atingissem os teores de água de interesse. Os recipientes utilizados para a secagem das sementes foram caixas tipo gerbox, que continham as soluções salinas ou a sílica gel. As caixas com as sementes foram acondicionadas em câmaras tipo BOD, à temperatura constante de $25^{\circ} \mathrm{C}$.

As características fisiológicas e bioquímicas das sementes, nos diferentes teores de água e nas diferentes velocidades de secagem, foram avaliadas em seguida à secagem e depois de quatro meses de armazenamento em câmara fria e seca, em condições herméticas. Para as avaliações, as sementes foram retiradas das embalagens, seus pergaminhos foram retirados manualmente, e elas foram deixadas em bancada, no laboratório, durante 24 horas, para o equilíbrio de temperatura.

Tabela 1. Sais e concentrações utilizados para a secagem lenta das sementes de Coffea arábica em diferentes umidades relativas (UR) de equilíbrio.

\begin{tabular}{lcc}
\hline Sal & Concentração & UR a 25 $5^{\circ} \mathrm{C}(\%)$ \\
\hline Cloreto de lítio $(\mathrm{LiCl})$ & 50 g por $1.000 \mathrm{~mL} \mathrm{H}_{2} \mathrm{O}$ & 95 \\
Cloreto de sódio $(\mathrm{NaCl})$ & Solução saturada & 75 \\
Cloreto de magnésio $\left(\mathrm{MgCl}_{2} . \mathrm{H}_{2} \mathrm{O}\right)$ & Solução saturada & 35 \\
\hline
\end{tabular}

O teor de água foi determinado pelo método de estufa a $105^{\circ} \mathrm{C}$, por 24 horas. Os resultados foram expressos em percentagens em BU, de acordo com as regras para análise de sementes (Regras..., 2009).

O teste de germinação foi realizado com quatro repetições, com 25 sementes cada, entre folhas de papel tipo germitest umedecidas com água em quantidade equivalente a 2,5 vezes o peso do papel seco. As sementes foram mantidas em germinador regulado para temperatura constante de $30^{\circ} \mathrm{C}$. A percentagem de plântulas normais foi avaliada após 30 dias (Regras..., 2009). As plântulas normais fortes, com hipocótilos iguais ou maiores do que $3 \mathrm{~cm}$, foram computadas 30 dias após a semeadura. Após 45 dias da semeadura, foram computadas as plântulas que apresentavam folhas cotiledonares expandidas (estádio "orelha de onça").

A massa de matéria seca de plântulas foi determinada após 45 dias da semeadura, quando os eixos hipocótilo-radículas das plântulas normais foram isolados, acondicionados em sacos de papel e secos em estufa de circulação forçada de ar, a $60^{\circ} \mathrm{C}$, por 5 dias ou até a obtenção de massa constante. Após esse período, foi determinada a massa de matéria seca de raízes e da parte aérea das plântulas, com resultados expressos em miligramas por plântula.

Para o teste de tetrazólio, foram utilizadas quatro repetições de 10 sementes cada. As sementes foram embebidas em água destilada por 48 horas a $30^{\circ} \mathrm{C}$ (Clemente et al., 2011). Após esse período, os embriões foram removidos, sem danos aos mesmos, com o auxílio de bisturi. Os embriões foram imersos em solução de tetrazólio a $0,5 \%$, em ambiente sem luz, pelo período de 3 horas, a $30^{\circ} \mathrm{C}$. Os resultados foram expressos em percentagem de embriões viáveis.

Para as análises bioquímicas, as sementes foram maceradas em nitrogênio líquido, em presença de polivinilpirrolidona (PVP), e armazenadas em "deep-freezer" a $-86^{\circ} \mathrm{C}$, até a realização das análises. Utilizou-se a metodologia proposta por Alfenas (2006), para a extração, corrida eletroforética e revelação das isoenzimas superóxido dismutase (SOD), catalase (CAT), esterase (EST) e peroxidase (PO).

Utilizou-se o delineamento experimental inteiramente casualizado, em arranjo fatorial $2 \times 6 \times 2$ : duas velocidades de secagem, seis teores de água nas sementes e dois períodos de armazenamento ( 0 e 4 meses). Os resultados foram submetidos à análise de 
variância, e as médias foram comparadas pelo teste de Scott-Knott, a 5\% de probabilidade (Ferreira, 2011).

\section{Resultados e Discussão}

A taxa de secagem diminuiu à medida que as sementes perderam água (Figura 1). Sementes com umidade inicial de $42 \% \mathrm{BU}$, submetidas à secagem rápida, levaram 577 horas para alcançar 4,2\% de umidade, à velocidade média de secagem de $0,062 \%$ por hora. Na secagem lenta, o tempo para que as sementes atingissem o teor de água próximo a $5 \%$ foi de 1.025 horas, à velocidade média de secagem de $0,034 \%$ por hora. No início, como as sementes estão completamente úmidas, a água apresenta propriedades similares a uma solução concentrada (Leprince et al., 2000) e, portanto, é retirada das sementes com relativa facilidade. Com o decréscimo do teor de umidade nas sementes, a água liga-se mais fortemente às superfícies coloidais das macromoléculas, o que torna mais difícil a secagem (Marcos Filho, 2005).

Ao longo dos quatro meses de armazenamento, as sementes apresentaram pequenas oscilações no teor de água (Tabela 2), com maior variação na umidade próxima a 30\% BU de sementes secadas em sílica gel.

Observou-se interação tripla significativa entre os fatores testados, quanto às percentagens de plântulas normais aos 30 dias, de plântulas normais fortes e de folhas cotiledonares expandidas; e quanto à massa de matéria seca de raiz. Para as variáveis viabilidade de sementes pelo teste de tetrazólio e massa de matéria

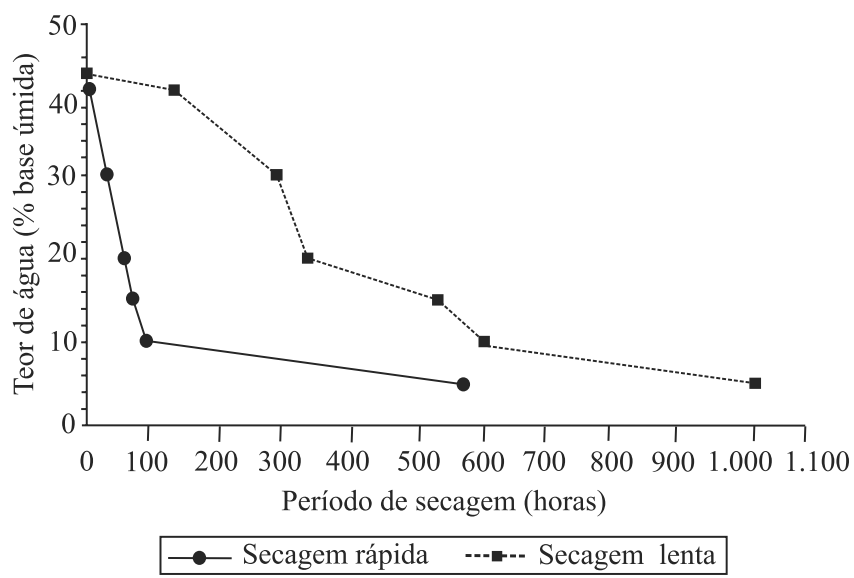

Figura 1. Variação no teor de água das sementes de Coffea arabica em função da secagem rápida, em sílica gel, e lenta, em soluções salinas saturadas. seca do hipocótilo, observou-se interação significativa entre teor de água e período de armazenamento ( 0 e 4 meses).

A umidade de $5 \%$ BU foi altamente prejudicial à germinação de sementes, avaliada pela percentagem de plântulas normais aos 30 dias, independentemente da velocidade em que as sementes foram secas (Figura 2). É interessante observar, no entanto, que após quatro meses de armazenamento, essas sementes aumentaram a percentagem de plântulas normais em relação à percentagem obtida logo após a secagem lenta. O armazenamento não produziu efeito sobre a germinação das sementes nas demais umidades avaliadas, com exceção das sementes submetidas à secagem rápida até $30 \% \mathrm{BU}$. José et al. (2011) verificaram que sementes de Magnólia ovata, uma espécie de comportamento intermediário, têm sua germinação mais prejudicada pela secagem rápida do que pela secagem lenta, para um mesmo conteúdo de água.

A viabilidade dos embriões não foi alterada após os quatro meses de armazenamento em câmara fria, exceto para as umidades de 5 e $30 \%$ BU (Figura 2). Os embriões das sementes armazenadas à umidade próxima de $40 \% \mathrm{BU}$ apresentaram alta viabilidade, tanto antes como depois dos quatro meses de armazenamento. $\mathrm{O}$ aumento na qualidade fisiológica das sementes secas até $5 \%$ após o armazenamento requer investigações adicionais, para

Tabela 2. Umidade média (\% de base úmida) de sementes de Coffea arabica, submetidas a diferentes velocidades de secagem, antes e após quatro meses de armazenamento em câmara fria e seca.

\begin{tabular}{lcc}
\hline Agente secante & \multicolumn{2}{c}{ Período de armazenamento } \\
\cline { 2 - 3 } & \multicolumn{2}{c}{ Secagem lenta } \\
\hline & 40,2 & 40,1 \\
Cloreto de lítio $(\mathrm{LiCl})$ & 29,3 & 29,4 \\
Cloreto de sódio $(\mathrm{NaCl})$ & 20,8 & 20,4 \\
Cloreto de magnésio $\left(\mathrm{MgCl}_{2} \cdot 6 \mathrm{H}_{2} \mathrm{O}\right)$ & 14,9 & 15,9 \\
Cloreto de magnésio $\left(\mathrm{MgCl}_{2} \cdot 6 \mathrm{H}_{2} \mathrm{O}\right)$ & 10,9 & 11 \\
Cloreto de magnésio $\left(\mathrm{MgCl}_{2} \cdot 6 \mathrm{H}_{2} \mathrm{O}\right)$ & 5,2 & 6,2 \\
Cloreto de magnésio $\left(\mathrm{MgCl}_{2} \cdot 6 \mathrm{H}_{2} \mathrm{O}\right)$ & \multicolumn{2}{c}{ Secagem rápida } \\
& 39,3 & 39,2 \\
Sílica gel & 31,8 & 29,6 \\
Sílica gel & 20,3 & 19,5 \\
Sílica gel & 15,0 & 14,0 \\
Sílica gel & 9,3 & 9,8 \\
Sílica gel & 4,2 & 6,1 \\
Sílica gel & \multicolumn{2}{c}{}
\end{tabular}


maior entendimento dos mecanismos relacionados à tolerância à dessecação e ao processo de deterioração das sementes de café durante o armazenamento.
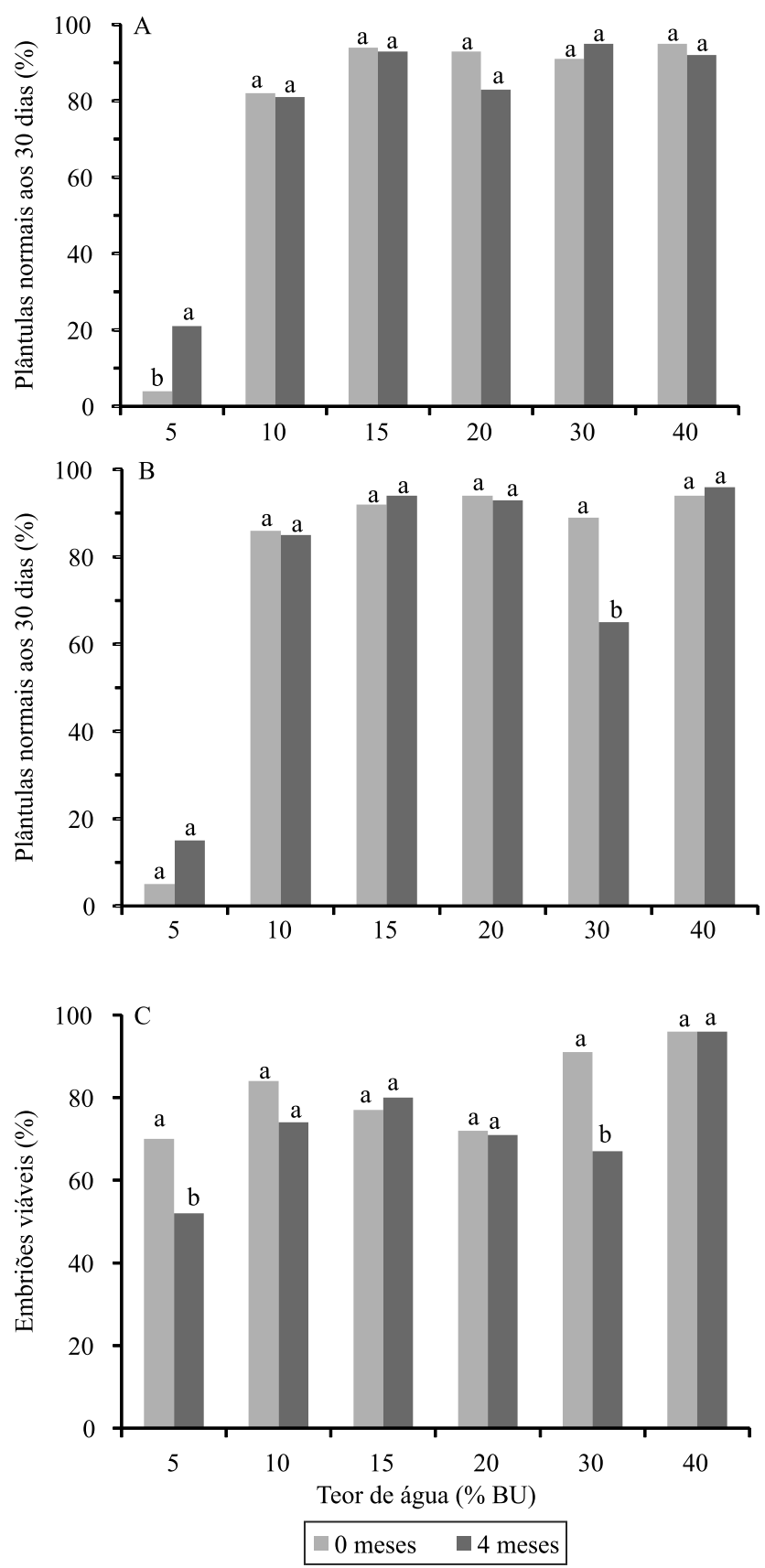

Figura 2. Percentagem média de plântulas normais, aos trinta dias, obtidas a partir de sementes de Coffea arabica submetidas às velocidades de secagem lenta $(\mathrm{A})$ e rápida $(\mathrm{B})$, e viabilidade de embriões pelo teste de tetrazólio (C); antes e depois do armazenamento em câmara fria e seca. Médias seguidas de letras iguais, para um mesmo teor de água, não difere pelo teste de Scott-Knott, a 5\% de probabilidade.
O nível crítico de umidade, considerado letal para sementes de café, situa-se entre 4 e 5\% (Ellis et al., 1990, 1991; Hong \& Ellis, 1992; Gentil, 2001). No presente estudo, entretanto, as sementes de café secas até $5 \%$ apresentaram alta viabilidade pelo teste de tetrazólio. Contudo, essas sementes não apresentaram bom desempenho na avaliação de plântulas normais, durante o teste de germinação (Figura 2). Esse resultado indica que os endospermas foram mais sensíveis à dessecação do que os embriões. O melhor desempenho fisiológico dos embriões, em comparação às sementes inteiras, corrobora os resultados de Dussert et al. (2006), que mostraram que há maior sensibilidade dos endospermas à secagem e à imersão em nitrogênio líquido, em comparação aos embriões zigóticos.

Em geral, as percentagens de plântulas normais fortes e de plântulas com folhas cotiledonares expandidas aos 45 dias, indicativas do vigor das sementes, diminuíram no decorrer do armazenamento (Figura 3). No entanto, para sementes submetidas à umidade de 5 e $40 \%$ BU, o vigor avaliado aumentou após o armazenamento. Esse resultado requer maior investigação, pois não é comum em estudos sobre armazenamento de sementes de café.

As sementes secas lentamente mantiveram o vigor, avaliado pela massa de matéria seca da raiz, após o armazenamento (Figura 3). Porém, na secagem rápida até 30 e $10 \% \mathrm{BU}$, esse vigor diminuiu após o armazenamento. Na maioria dos testes de vigor, observou-se redução na qualidade das sementes após o armazenamento em câmara fria e seca, contrariamente aos resultados do teste de germinação, em que houve manutenção da qualidade (Figura 2). Vieira et al. (2007) observaram que sementes de café têm sua emergência e índice de velocidade de emergência linearmente diminuídos ao longo do armazenamento por nove meses, e que a secagem rápida prejudica seu vigor e viabilidade, independentemente do local de armazenamento. Os autores também observaram que, em condições de câmara fria e seca, é possível armazenar sementes de café sem secagem ou secas lentamente, pelo período de nove meses. Rosa et al. (2005) relataram que a redução no teor de água de sementes de $C$. canephora diminuiu seus valores de germinação e de vigor, nas diferentes taxas de secagem avaliadas.

Quanto à avaliação enzimática, observou-se maior atividade da enzima esterase nas sementes de café 

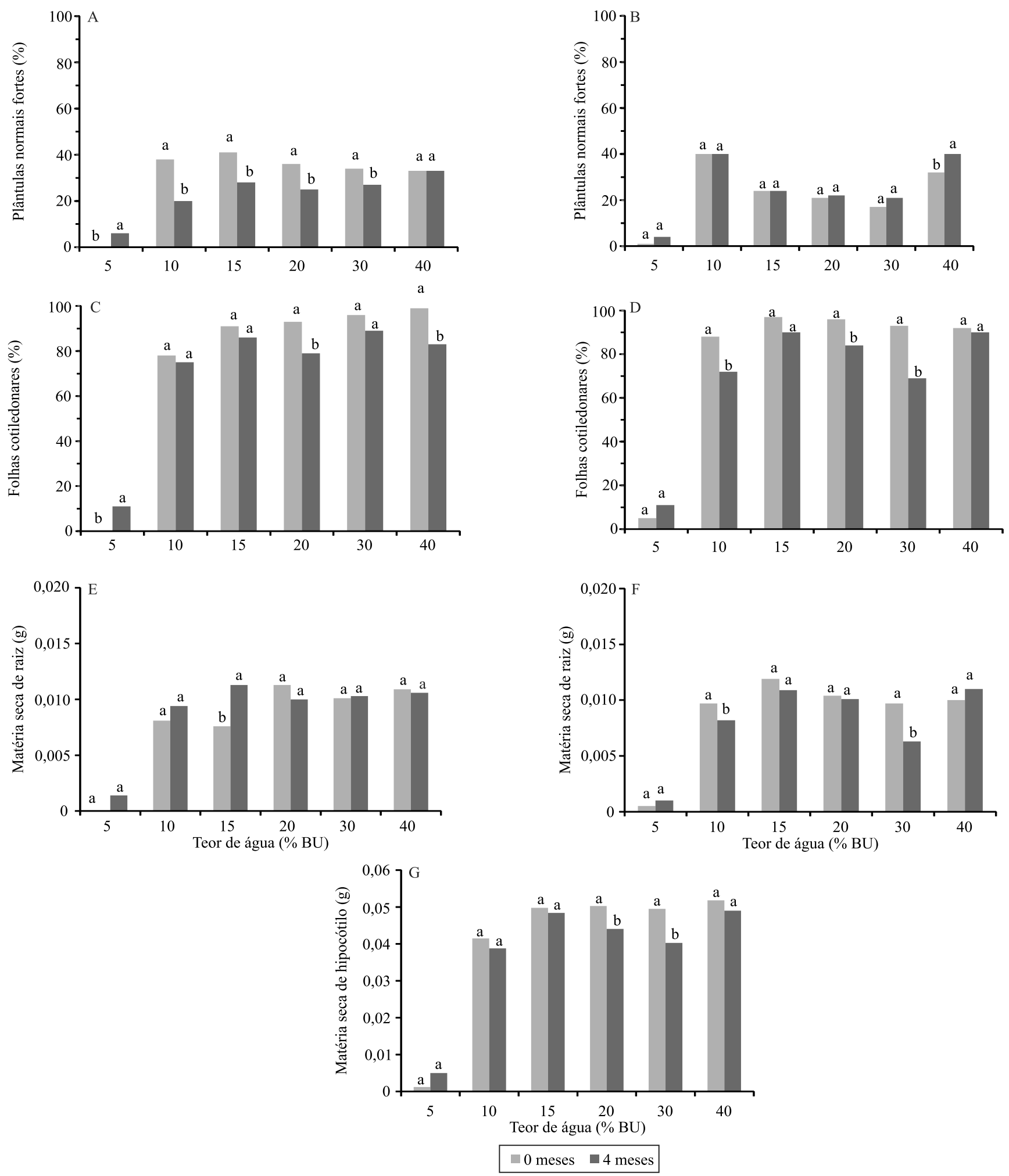

Figura 3. Percentagem média de plântulas normais fortes, folhas cotiledonares expandidas e matéria seca de raízes de plântulas (interação tripla significativa) de sementes de Coffea arabica submetidas à secagem lenta $(\mathrm{A}, \mathrm{C}$ e E) e rápida $(\mathrm{B}, \mathrm{C}$ e F), e massa de matéria seca do hipocótilo (G); antes e depois do armazenamento em câmara fria e seca. Médias seguidas de letras iguais, para um mesmo teor de água, não difere pelo teste de Scott-Knott, a 5\% de probabilidade. 
submetidas à secagem rápida (Figura 4). Sementes de café úmidas $(40 \% \mathrm{BU})$ apresentaram menor atividade da esterase, e à medida que as sementes perderamágua, a expressão dessa enzima aumentou, independentemente do método de secagem. No entanto, após o período de armazenamento, a atividade da esterase diminuiu em sementes secas lentamente até 30 e $20 \%$ BU, em comparação às sementes não armazenadas.

$\mathrm{O}$ aumento da atividade da esterase coincidiu com a redução da qualidade fisiológica das sementes, que diminuiu à medida que as sementes foram submetidas à secagem. Esse resultado pode estar associado à maior peroxidação de lipídeos nas membranas das sementes secas e ao consequente processo degenerativo das membranas (Santos et al., 2005), uma vez que a enzima está envolvida em reações de hidrólise de ésteres e participa diretamente do metabolismo de lipídeos. Brandão Júnior et al. (2002) observaram que essa enzima aumenta a atividade e apresenta maior número de bandas em sementes de café envelhecidas ou danificadas.

Em sementes submetidas à secagem rápida, a atividade da peroxidase aumentou com a diminuição no teor de água, com maior expressão nas umidades de 10 e $5 \%$ BU (Figura 4). Na secagem lenta, sementes com $30 \%$ BU apresentaram menor atividade da enzima, tanto antes como após o armazenamento. A atividade da catalase apresentou comportamento semelhante ao da peroxidase, com aumento na expressão da enzima
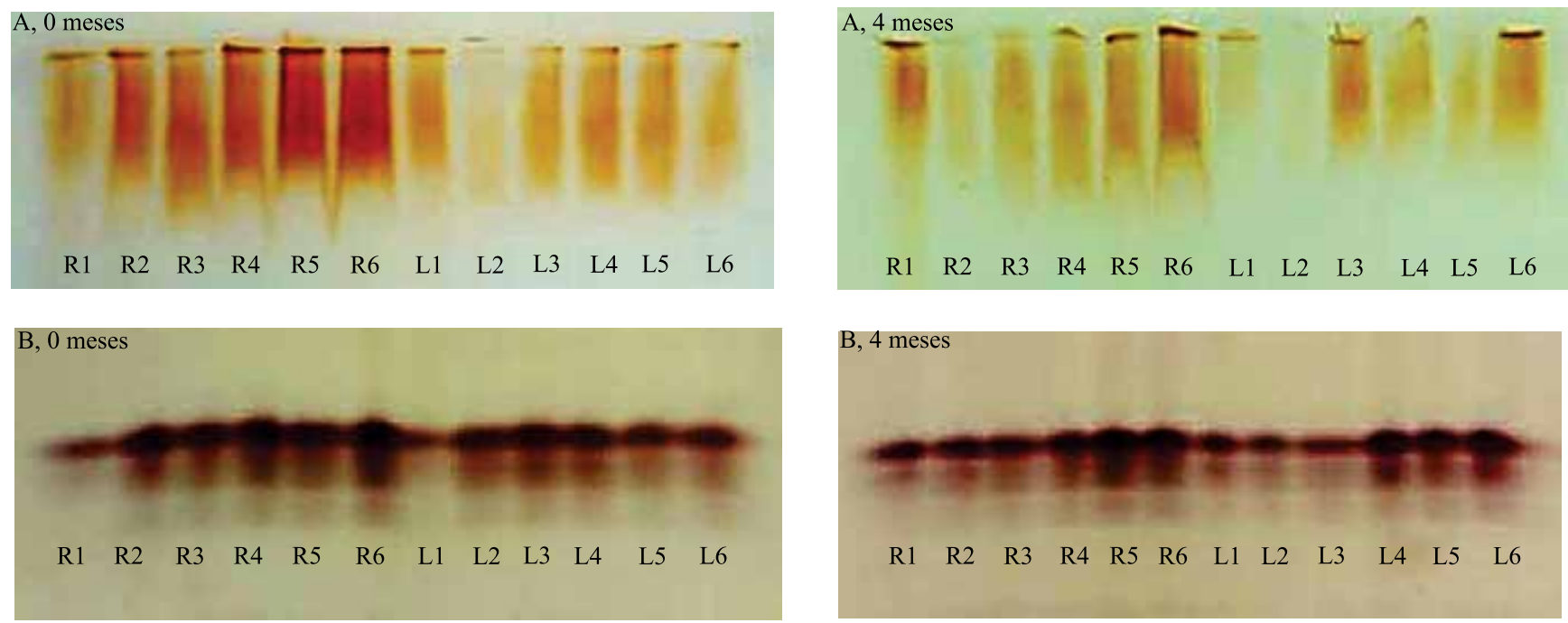

Figura 4. Padrão eletroforético das isoenzimas peroxidase $(\mathrm{A})$ e esterase $(\mathrm{B})$, em sementes de Coffea arabica, submetidas às velocidades de secagem rápida, $\mathrm{R}$, e lenta $\mathrm{L}$, até a obtenção de diferentes teores de água $-1,40 \% ; 2,30 \% ; 3,20 \% ; 4,15 \%$; $5,10 \%$; e 6, 5\% -, e armazenadas durante 0 e 4 meses em câmara fria e seca. 

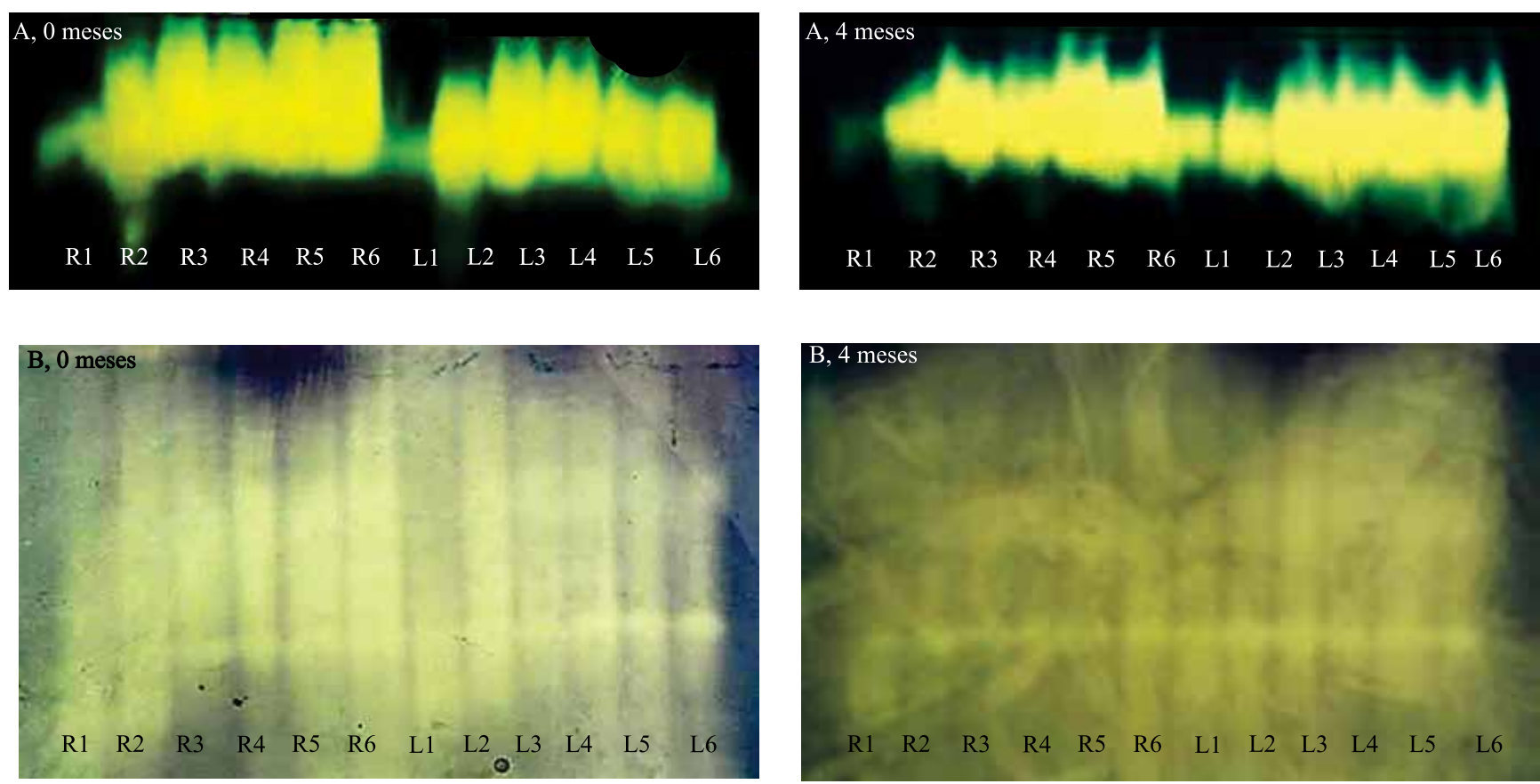

Figura 5. Padrão eletroforético das isoenzimas catalase (A) e superóxido dismutase (B), em sementes de Coffea arabica submetidas às velocidades de secagem rápida, $\mathrm{R}$, e lenta $\mathrm{L}$, até a obtenção de diferentes teores de água - 1, 40\%; $2,30 \% ; 3$, $20 \% ; 4,15 \% ; 5,10 \%$; e 6, 5\% -, e armazenadas durante 0 e 4 meses em câmara fria e seca.

\section{Conclusões}

1. Os prejuízos da secagem à qualidade fisiológica das sementes de café dependem da velocidade com que a água é retirada e do teor final de água nas sementes.

2. Com a secagem rápida, as sementes de café toleram dessecação a menores teores de água, mas a qualidade das sementes secas até teores mais elevados de água é menor do que a de sementes secas lentamente.

3. O armazenamento pelo período de quatro meses não afeta a germinação, porém prejudica o vigor das sementes de café.

4. A percentagem de plântulas normais próxima de zero, no teste de germinação de sementes secas até 5\% de umidade, contrasta com a elevada viabilidade dos embriões no teste de tetrazólio e indica que os danos da secagem estão mais relacionados aos endospermas.

5. O perfil enzimático em sementes de café é afetado pelo teor de água das sementes e pela velocidade de secagem.

\section{Agradecimentos}

À Coordenação de Aperfeiçoamento de Pessoal de Nível Superior (Capes), ao Conselho Nacional de
Desenvolvimento Científico e Tecnológico (CNPq), à Fundação de Amparo à Pesquisa do Estado de Minas Gerais (Fapemig), à Universidade Federal de Lavras (Ufla), pelo apoio financeiro.

\section{Referências}

ALFENAS, A.C. Eletroforese e marcadores bioquímicos em plantas e microrganismos. 2.ed. Viçosa: Ed. da UFV, 2006. 627p. BAZIN, J.; BATLLA, D.; DUSSERT, S.; MAAROUF-BOUTEAU, H.; BAILLY, C. Role of relative humidity, temperature, and water status in dormancy alleviation of sunflower seeds during dry after-ripening. Journal of Experimental Botany, v.62, p.627-640, 2011. DOI: $10.1093 /$ jxb/erq314.

BERJAK, P. Unifying perspectives of some mechanisms basic to desiccation tolerance across life forms. Seed Science Research, v.16, p.1-15, 2006. DOI: 10.1079/SSR2005236.

BRANDÃO JÚNIOR, D. da S.; VIEIRA, M. das G.G.C.; HILHOST, H.W.M. Aquisição da tolerância à dessecação nos diferentes estádios de desenvolvimento de sementes de cafeeiro (Coffea arabica L.). Ciência e Agrotecnologia, v.26, p.673-681, 2002.

CADDAH, M.K.; ANDRADE, B.O.; MEDEIROS, A.C.S. Efeitos da desidratação e do armazenamento em sementes de Magnolia ovata St. Hil. Magnoliaceae. Informativo ABRATES, v.15, p.285, 2005. 
CARVALHO, L.R. de. Conservação de sementes de espécies dos gêneros Nectandra, Ocotea e Persea (Lauraceae). 2006. 75p. Tese (Doutorado) - Universidade Federal de Lavras, Lavras.

CHOUDHURY, D.; SAHU, J.K.; SHARMA, G.D. Moisture sorption isotherms, heat of sorption and properties of sorbed water of raw bamboo (Dendrocalamus longispathus) shoots. Industrial Crops and Products, v.33, p.211-216, 2011. DOI: 10.1016/j. indcrop.2010.10.014.

CLEMENTE, A. da C.S.; CARVALHO, M.L.M. de; GUIMARÃES, R.M.; ZEVIANI, W.M. Preparo das sementes de café para a avaliação da viabilidade pelo teste de tetrazólio. Revista Brasileira de Sementes, v.33, p.38-44, 2011. DOI: 10.1590/S0101-31222011000100004.

DUSSERT, S.; COUTURON, E.; ENGELMANN, F.; JOËT, T. Biologie de la conservation des semences de caféiers: aspects fondamentaux et conséquences pratiques. Une revue. Cahiers Agricultures, v.21, p.106-114, 2012. DOI: 10.1684/agr.2012.0552.

DUSSERT, S.; DAVEY, M.W.; LAFFARGUE, A.; DOULBEAU, S.; SWENNEN, R.; ETIENNE, H. Oxidative stress, phospholipid loss and lipid hydrolysis during drying and storage of intermediate seeds. Physiologia Plantarum, v.127, p.192-204, 2006. DOI: 10.1111/j.1399-3054.2006.00666.x.

ELLIS, R.H.; HONG, T.D.; ROBERTS, E.H. An intermediate category of seed storage behaviour? I. Coffee. Journal of Experimental Botany, v.41, p.1167-1174, 1990. DOI: 10.1093/ $\mathrm{jxb} / 41.9 .1167$.

ELLIS, R.H.; HONG, T.D.; ROBERTS, E.H. Effect of storage temperature and moisture content on the germination of papaya seeds. Seed Science Research, v.1, p.69-72, 1991. DOI: 10.1017/ S0960258500000659.

FERREIRA, D.F. Sisvar: a computer statistical analysis system. Ciência e Agrotecnologia, v.35, p.1039-1042, 2011. DOI: 10.1590/S1413-70542011000600001.

GENTIL, D.F. de O. Conservação de sementes do cafeeiro: resultados discordantes ou complementares? Bragantia, v.60, p.333-338, 2001. DOI: 10.1590/S0006-87052001000300001.

HAY, F.R.; ADAMS, J.; MANGER, K.; PROBERT, R. The use of non-saturated lithium chloride solutions for experimental control of seed water content. Seed Science and Technology, v.36, p.737-746, 2008. DOI: 10.15258/sst.2008.36.3.23.

HONG, T.D.; ELLIS, R.H. Optimum air-dry seed storage environments for arabica coffee. Seed Science and Technology, v.20, p.547-560, 1992.

ILLING, N.; DENBY, K.J.; COLLETT, H.; SHEN, A.; FARRANT, J.M. The signature of seeds in resurrection plants: a molecular and physiological comparison of desiccation tolerance in seeds and vegetative tissues. Integrative and Comparative Biology, v.45, p.771-787, 2005. DOI: $10.1093 / \mathrm{icb} / 45.5 .771$.
JOSÉ, A.C.; DA SILVA, E.A.A.; DAVIDE, A.C.; MELO, A.J.S.; TOOROP, P.E. Effects of drying rate and storage time on Magnolia ovata Spreng. seed viability. Seed Science and Technology, v.39, p.425-434, 2011. DOI: 10.15258/sst.2011.39.2.14.

JOSÉ, S.C.B.R.; SALOMÃO, A.N.; MUNDIM, R.C.; PÁDUA, J.G. Umidificação de sementes de girassol após ultrassecagem em sílica gel e câmara de secagem. Revista Brasileira de Sementes, v.31, p.16-26, 2009. DOI: 10.1590/S0101-31222009000300002.

LEPRINCE, O.; HARREN, F.J.M.; BUITINK, J.; ALBERDA, M.; HOEKSTRA, F.A. Metabolic dysfunction and unabated respiration precede the loss of membrane integrity during dehydration of germinating radicles. Plant Physiology, v.122, p.597-608, 2000. DOI: $10.1104 / \mathrm{pp} .122 .2 .597$.

LI, C.; SUN, W.Q. Desiccation sensitivity and activities of free radical-scavenging enzymes in recalcitrant Theobroma cacao seeds. Seed Science Research, v.9, p.209-217, 1999. DOI: $10.1017 / \mathrm{S} 0960258599000215$.

MARCOS FILHO, J. Fisiologia de sementes de plantas cultivadas. Piracicaba: FEALQ, 2005. 495p. (FEALQ. Biblioteca de Ciências Agrárias Luiz de Queiroz, 12).

NKANG, A.; OMOKARO, D.; EGBE, A. Effects of desiccation on the lipid peroxidation and activities of peroxidase and polyphenoloxidase in seeds of Telfairia occidentalis. Seed Science and Technology, v.28, p.1-9, 2000.

REGRAS para análise de sementes. Brasília: Ministério da Agricultura, Pecuária e Abastecimento, Secretaria de Defesa Agropecuária, 2009. 399p.

ROBERTS, E.H. Predicting the storage life of seeds. Seed Science and Tecnology, v.1, p.499-514, 1973.

ROSA, S.D.V.F. da; BRANDÃO JÚNIOR, D. da S.; VON PINHO, E.V. de R.; VEIGA, A.D.; SILVA, L.H. de C. Effects of different drying rates on the physiological quality of Coffea canephora Pierre seeds. Brazilian Journal of Plant Physiology, v.17, p.199-205, 2005. DOI: $10.1590 /$ S1677-04202005000200002.

SANTOS, C.M.R.; MENEZES, N.L. de; VILLELA, F.A. Modificações fisiológicas e bioquímicas em sementes de feijão no armazenamento. Revista Brasileira de Sementes, v.27, p.104-114, 2005. DOI: 10.1590/S0101-31222005000100013.

SILVA, P. de A.; DINIZ, K.A.; OLIVEIRA, J.A.; VON PINHO, E.V. de R. Análise fisiológica e ultra-estrutural durante $\mathrm{o}$ desenvolvimento e a secagem de sementes de soja. Revista Brasileira de Sementes, v.29, p.15-22, 2007. DOI: 10.1590/ S0101-31222007000200003.

VIEIRA, A.R.; OLIVEIRA, J.A.; GUIMARÃES, R.M.; PEREIRA, C.E.; CARVALHO, F.E. de. Armazenamento de sementes de cafeeiro: ambientes e métodos de secagem. Revista Brasileira de Sementes, v.29, p.76-82, 2007. DOI: 10.1590/ S0101-31222007000100011.

Recebido em 19 de dezembro de 2014 e aprovado em 30 de abril de 2015 